\title{
Analisis Kinerja Keuangan Dengan Menggunakan Rasio-Rasio Keuangan Dan Economic Value Added (EVA) Pada PT. Bank Muamalat Indonesia Tbk.
}

\author{
Ahmad Mukhlis ${ }^{1}$, Novanda Puspha Zahra ${ }^{2}$ \\ ${ }^{1,2}$ Universitas Bina Bangsa Banten \\ E-mail: ahmuk999@gmail.com ${ }^{1}$, novandapuspha@gmail.com ${ }^{2}$
}

\begin{tabular}{ll} 
ARTICLE INFO & ABSTRACT \\
\hline Keywords: & The purpose of this study is to determine the financial performance of Muamalat \\
ROA, & Indonesia Tbk. bank by using financial ratios and Economic Value Added (EVA) \\
ROE, & period 2013-2017. The research is a type of qualitative research with descriptive \\
NPM, & As for the results of the study is the highest ROA value is in the year 2013 because it is \\
CAR, & above the standard, the value of bank ROE tends to decline from year to year, the \\
DAR, & value of NPM bank fluctuate every year, the CAR value of the bank can categorized \\
DER, & well because it is always above standard, DER and DAR fluctuate every year, while \\
Economic Value Added & positive EVA values are only in 2015 \\
(EVA) &
\end{tabular}

\section{PENDAHULUAN}

Dewasa ini banyak lembaga-lembaga keuangan yang besar peranannya didalam perekonomian Indonesia. Namun salah satu dari lembaga-lembaga keuangan tersebut yang nampaknya paling besar peranannya adalah bank. Selain Bank konvensional, muncul pula yang berbasis Syariah. PT. Bank Muamalat Indonesia Tbk. ("Bank Muamalat Indonesia") didirikan pada 1 November 1991, digagas oleh Majelis Ulama Indonesia (MUI), Ikatan Cendekiawan Muslim Indonesia (ICMI), serta pengusaha muslim dengan dukungan Pemerintah Republik Indonesia dan beroperasi pada 1 Mei 1992. Sebagai bank syariah pertama di Indonesia, Bank Muamalat Indonesia merupakan inisiator bisnis keuangan syariah lainnya antara lain; Asuransi syariah pertama (Asuransi Takaful), Dana pensiun lembaga keuangan Muamalat (DPLK Muamalat) dan multifinance syariah pertama (Al-Ijarah Indonesia Finance). Bank Muamalat Indonesia mendapatkan ijin sebagai Bank Devisa pada 27 Oktober 1994 dan merupakan perusahaan publik namun tidak listing di Bursa Efek Indonesia (BEI). Bank Muamalat Indonesia telah melakukan Penawaran Umum Terbatas (PUT) dengan Hak Memesan Efek Terlebih Dahulu (HMETD) sebanyak 5 (lima) kali dan merupakan lembaga perbankan pertama di Indonesia yang mengeluarkan Sukuk Subordinasi Mudharabah di tahun 2003. Dalam melakukan ekspansi bisnisnya, selain membuka kantor cabang di seluruh wilayah Indonesia, Bank Muamalat Indonesia juga membuka kantor cabang internasional di Kuala Lumpur, Malaysia pada tahun 2009 dan tercatat sebagai bank pertama dan satu-satunya dari Indonesia yang membuka jaringan bisnis di Malaysia. Walaupun berdiri sejak tahun 1991 dan sudah menjadi perusahaan terbuka dengan menawarkan sahamnya ke publik tanpa masuk bursa efek, baru pada tanggal 5 Juli 2013 Bank Muamalat Indonesia mengumumkan resmi menjual lagi sahamnya ke publik di penawaran saham kedua.

Rasio CAR Bank Muamalat Indonesia tercatat masih berada sedikit di atas ketetapan OJK berdasarkan profil risiko bank sebesar 10 persen. Pada Oktober 2017 PT. Mina Padi Investama Sekuritas Tbk. menjadi pembeli siaga (standby buyer) pada proses penerbitan saham baru melalui Hak Memesan Efek Terlebih Dahulu (HMETD) atau rights issue dengan target dana Rp. 4,5 triliun. Keduanya telah menandatangani perjanjian jual beli bersyarat dan PT. Mina Padi Investama Tbk. menyetorkan dana Rp. 1,7 triliun ke rekening escrow sebagai penempatan dana guna menghindari perselisihan dalam perjanjian kedua belah pihak hingga kontrak terpenuhi atau dibatalkan. Escrow merupakan perjanjian legal ketika sebuah barang (umumnya berupa uang) disimpan oleh pihak ketiga, sementara menunggu isi kontrak terpenuhi. Kendati batal, dana PT. Mina Padi Investama Tbk. di rekening escrow tersebut tetap diperhitungkan sebagai 
modal oleh Bank Mualamat Indonesia. Sehingga di akhir tahun 2017 lalu, modal inti bank syariah tertua di Indonesia ini melonjak Rp. 1,66 triliun dibanding tahun 2016, menjadi Rp. 4,99 triliun.

Data berikut ini merupakan fenomena kinerja keuangan bank periode tahun 2013-2017 dilihat dari sudut Return on Asset (ROA), Return on Equity (ROE), dan Capital Adequacy Ratio (CAR) pada Bank Muamalat Indonesia:

Tabel 1.1 ROA, ROE, CAR Bank Muamalat Indonesia Tbk.

\begin{tabular}{|c|c|c|c|}
\hline Tahun & ROA & ROE & CAR \\
\hline 2013 & $1,37 \%$ & $32,87 \%$ & $17,27 \%$ \\
\hline 2014 & $0,17 \%$ & $2,13 \%$ & $14,15 \%$ \\
\hline 2015 & $0,20 \%$ & $2,78 \%$ & $12,36 \%$ \\
\hline 2016 & $0,22 \%$ & $3,00 \%$ & $12,74 \%$ \\
\hline 2017 & $0,11 \%$ & $0,87 \%$ & $13,62 \%$ \\
\hline
\end{tabular}

Sumber: Laporan Keuangan Tahunan Bank Muamalat Indonesia

Untuk mengukur kinerja Bank Muamalat Indonesia Tbk. dapat dilakukan penilaian dengan menggunakan rasio keuangan. Namun kinerja dan prestasi manajemen yang diukur dengan rasio keuangan dinilai kurang dapat mewakili kondisi perusahaan yang sebenarnya. Sehingga diperlukan metode lain untuk mengukur kinerja Bank Muamalat Indonesia, salah satunya adalah dengan metode Economic Value Added (EVA). Metode EVA dapat melengkapi kekurangan yang dimiliki oleh rasio keuangan dan lebih akurat dalam mengukur kinerja dan menghitung nilai tambah yang diciptakan perusahaan.

Dari pendahuluan diatas maka dapat diidentifikasi masalah adalah sebagai berikut:

1. Return on Asset (ROA) Bank Muamalat Indonesia pada tahun 2013-2017 berfluktuasi dengan nilai terendah sebesar $0,11 \%$ pada tahun 2017

2. Return on Equity (ROE) Bank Muamalat Indonesia pada tahun 2017 mengalami penurunan yang tajam hingga pada titik terendah sebesar $0,87 \%$

3. Capital Adequacy Ratio (CAR) Bank Muamalat Indonesia pada tahun 2013-2017 berfluktuasi dengan kecenderungan menurun

\section{STUDI PUSTAKA}

\section{Kinerja Keuangan}

Kinerja keuangan adalah hasil atau prestasi yang telah dicapai oleh manajemen perusahaan dalam menjalankan fungsinya mengelola asset perusahaan secara efektif selama periode tertentu. Pengukuran kinerja adalah salah satu faktor yang sangat penting dilakukan bagi suatu perusahaan, dimana dari adanya pengukuran tersebut dapat mempengaruhi pengambilan keputusan dalam perusahaan (Rudianto, 2013:189). Kinerja keuangan merupakan gambaran dari pencapaian keberhasilan perusahaan dapat diartikan sebagai hasil yang telah dicapai atas berbagai aktivitas yang telah dilakukan. Dapat dijelaskan bahwa kinerja keuangan adalah suatu analisis yang dilakukan untuk melihat sejauh mana suatu perusahaan telah melaksanakan dengan menggunakan aturan-aturan pelaksanaan keuangan secara baik dan benar (Irham Fahmi, 2014:2).

Kinerja keuangan merupakan gambaran kondisi keuangan perusahaan pada suatu periode tertentu menyangkut aspek penghimpunan dana maupun penyaluran dana, yang biasanya diukur dengan indikator kecukupan modal, likuiditas, dan profitabilitas (Jumingan, 2014:239).

\section{Rasio-Rasio Keuangan}

Rasio keuangan merupakan kegiatan membandingkan angka-angka yang ada dalam laporan keuangan dengan cara membagi satu angka dengan angka yang lainnya. Perbandingan dapat dilakukan antara satu komponen dengan komponen dalam satu laporan keuangan. Kemudian angka yang diperbandingkan dapat berupa angka-angka dalam satu periode maupun beberapa periode. Hasil dari rasio keuangan inilah yang digunakan untuk menilai kinerja manajemen dalam suatu periode apakah mencapai target seperti yang telah ditetapkan atau sebaliknya. Disamping itu juga untuk menilai kemampuan manajemen dalam memberdayakan sumber daya perusahaan secara efektif dan efisien 
(Kasmir, 2016:95). Rasio-rasio keuangan umumnya digolongkan menjadi menjadi empat, yaitu Rasio Likuiditas; Rasio Aktivitas; Rasio Solvabilitas dan Rasio Rentabilitas/Profitabilitas.

Rasio-rasio yang digunakan dalam penelitian ini yaitu hanya rasio profitabilitas dan rasio solvabilitas. Rasio Profitabilitas adalah rasio untuk mengukur efektivitas manajemen secara keseluruhan yang ditujukan oleh besar kecilnya tingkat keuntungan yang diperoleh dalam hubungannya dengan penjualan maupun investasi. Semakin baik rasio profitabilitas maka semakin baik menggambarkan kemampuan tingginya perolehan keuntungan perusahaan (Irham Fahmi, 2014:68). Rasio solvabilitas adalah rasio untuk mengukur seberapa besar perusahaan dibiayai dengan utang. Penggunaan utang yang terlalu tinggi akan membahayakan perusahaan, karena perusahaan akan masuk dalam kategori utang ektrem yaitu perusahaan terjebak dalam tingkat utang yang tinggi dan sulit untuk melepaskan beban utang tersebut (Irham Fahmi, 2014:62).

\section{Economic Value Added (EVA)}

Economic Value Added (EVA) merupakan alat pengukur kinerja perusahaan, dimana kinerja perusahaan diukur dengan melihat selisih antara tingkat pengembalian modal dan biaya modal, kemudian dikalikan dengan modal yang beredar pada awal tahun (Rudianto, 2013:217). Dalam menghitung nilai Economic Value Added (EVA) ada beberapa tahapan. EVA dihitung setelah semua komponen pembentuknya diketahui. Selanjutnya dimasukkan kedalam rumus perhitungan EVA. Adapun tahapan-tahapan dalam perhitungan EVA ditunjukkan dibawah ini:

1. Net Operating Profit After Tax (NOPAT)

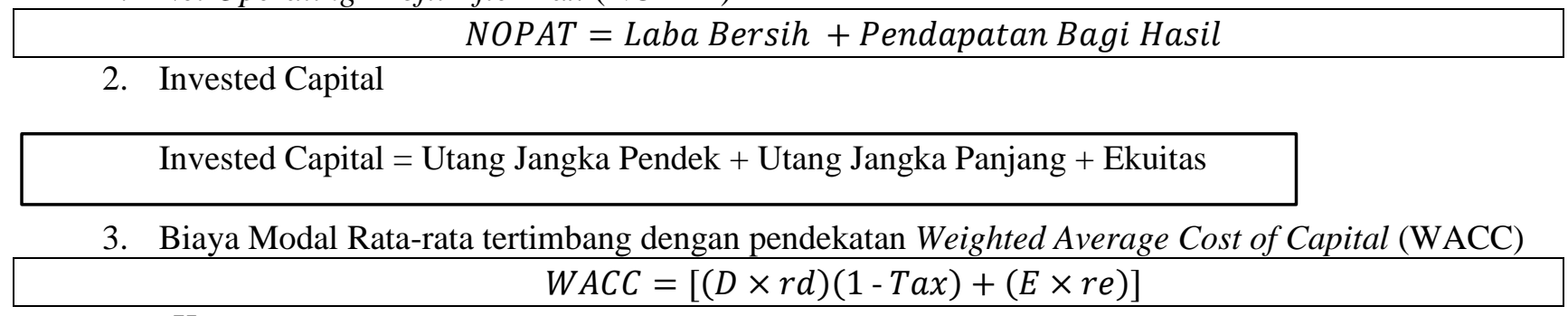

Keterangan:

a. Tingkat Modal dari Utang $(\mathrm{D})=$

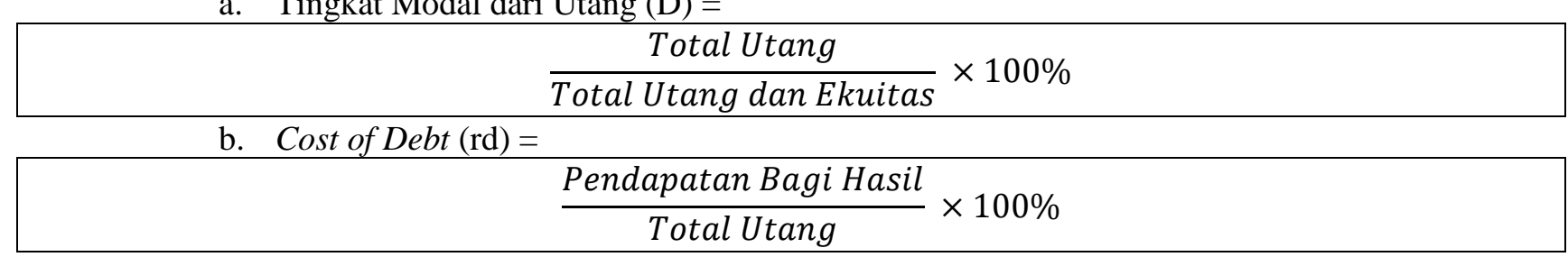

c. $\quad$ Cost of Equity (re) $=$

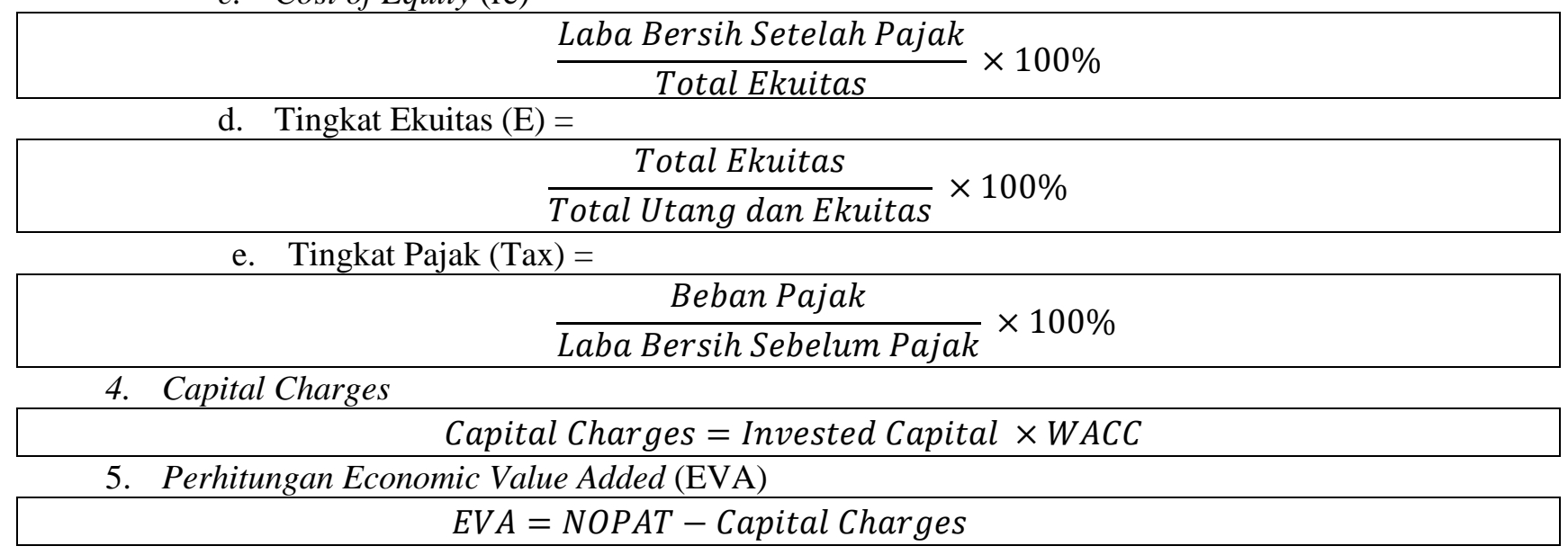




\section{METODOLOGI PENELITIAN}

\section{Metode}

Penelitian ini menggunakan metode kualitatif deskriptif. Metode deskriptif merupakan metode penelitian dengan cara mengumpulkan data yang sebenarnya, kemudian data tersebut disusun, diolah, dan dianalisis untuk dapat memberikan gambaran mengenai masalah yang ada.

\section{Data dan Sumber Data}

Data yang digunakan dalam penelitian ini adalah data kuantitatif yang berupa laporan keuangan yang terdiri dari neraca dan laporan laba/rugi.

Sedangkan sumber data yang digunakan dalam penelitian ini adalah sumber data sekunder berupa laporan neraca dan laporan laba/rugi keuangan Bank Muamalat Indonesia periode 2013-2017. Data sekunder adalah data yang diperoleh dalam bentuk yang sudah jadi, sudah dikumpulkan dan diolah oleh pihak lain, biasanya sudah dalam bentuk publikasi. Sumber data berupa laporan keuangan tersebut di dapatkan dari situs resmi Bank Muamalat Indonesia yang ada kaitannya dengan masalah yang sedang diteliti.

\section{Prosedur Analisis Data}

1. Rasio Profitabilitas

Rasio Profitabilitas beserta rumus yang digunakan dalam penelitian ini yaitu sebagai berikut:
a) Net Profit Margin (NPM) $=\frac{\text { Laba Bersih }}{\text { Pendapatan Operasional }} \times 100 \%$
b) Return On Asset (ROA) $=\frac{\text { Laba Bersih }}{\text { TotalAktiva }} \times 100 \%$
c) Return on Equity $(\mathrm{ROE})=\frac{\text { Laba Bersih }}{\text { Ekuitas }} \times 100 \%$

2. Rasio Solvabilitas
a) $\quad C A R=\frac{\text { Modal Bank }}{\text { Aktiva Tertimbang Menurut Risiko (ATMR) }} \times 100 \%$
b) $D E R=\frac{\text { Total Hutang }}{\text { Total Ekuitas }} \times 100 \%$
c) $D A R=\frac{\text { Total Hutang }}{\text { Total Aktiva }} \times 100 \%$

\section{Economic Value Added (EVA)} berikut:

Dalam mencari nilai EVA diperlukan beberapa tahapan perhitungan dengan rumus sebagai

1) Net Operating Profit After Tax (NOPAT)

2) Invested Capital (IC)

$$
\text { NOPAT = Laba Bersih + Pendapatan Bagi Hasil }
$$

$$
I C=\text { Utang Jangka Pendek + Utang Jangka Panjang + Ekuitas }
$$

3) Biaya Modal Rata-rata tertimbang dengan pendekatan Weighted Average Cost of Capital (WACC)

\section{Keterangan:}

$$
W A C C=[(D \times r d)(1-T a x)+(E \times r e)]
$$

a. Tingkat Modal dari Utang (D)

$$
\mathrm{D}=\frac{\text { Total Utang }}{\text { Total Utang dan Ekuitas }} \times 100 \%
$$

b. Cost of Debt (rd)

$$
\mathrm{Rd}=\frac{\text { Pendapatan Bagi Hasil }}{\text { Total Utang }} \times 100 \%
$$

c. Cost of Equity (re)

$$
\mathrm{Re}=\frac{\text { Laba Bersih Setelah Pajak }}{\text { Total Ekuitas }} \times 100 \%
$$


d. Tingkat Ekuitas (E)

$\mathrm{E}=\frac{\text { Total Ekuitas }}{\text { Total Utang dan Ekuitas }} \times 100 \%$

e. Tingkat Pajak (Tax)

Tax $=\frac{\text { Beban Pajak }}{\text { Laba Bersih Sebelum Pajak }} \times 100 \%$

\section{4) Capital Charges}

$$
\text { Capital Charges }=\text { Invested Capital } \times \text { WACC }
$$

5) Perhitungan Economic Value Added (EVA)

$$
E V A=\text { NOPAT + Capital Charges }
$$

Untuk mengetahui tingkat kesehatan kinerja keuangan perbankan diperlukan standar nilai. Berikut ini adalah tabel standar nilai NPM, ROA, ROE, CAR, DER, DAR dan Economic Value Added (EVA):

Tabel 3.1 Standar nilai NPM, ROA, ROE, CAR, DER, DAR dan Economic Value Added (EVA)

\begin{tabular}{|l|c|}
\hline \multicolumn{1}{|c|}{ Indikator } & Standar Nilai \\
\hline Net Profit Margin (NPM) & Semakin tinggi maka semakin baik \\
\hline Return on Asset (ROA) & $0,5 \%-1,25 \%$ \\
\hline Return on Equity (ROE) & $17,5 \%$ \\
\hline Capital Adequacy Ratio (CAR) & $8 \%$ \\
\hline Debt to Equity Ratio (DER) & Semakin rendah maka semakin baik \\
\hline Debt to Asset Ratio (DAR) & Semakin rendah maka semakin baik \\
\hline Economic Value Added (EVA) & EVA $>0$ \\
\hline
\end{tabular}

\section{HASIL PENELITIAN DAN PEMBAHASAN}

\section{Rasio Profitabilitas berdasarkan Net Profit Margin (NPM)}

Dengan rumus berikut: $N P M=\frac{\text { Laba Bersih }}{\text { Laba Operasional }} \times 100 \%$

Didapatkan hasil perhitungan sebagai berikut:

Tabel 4.1 Net Profit Margin (NPM) Bank Muamalat Indonesia

\begin{tabular}{|c|c|c|c|}
\hline Tahun & $\begin{array}{c}\text { Laba Bersih } \\
\text { (dalam jutaan } \\
\text { rupiah) }\end{array}$ & $\begin{array}{c}\text { Laba Operasional } \\
\text { (dalam jutaan } \\
\text { rupiah) }\end{array}$ & $\begin{array}{c}\text { Net Profit Margin } \\
\text { (NPM) }\end{array}$ \\
\hline 2013 & 475.847 & 708.676 & $67,14 \%$ \\
\hline 2014 & 57.173 & 147.853 & $38,66 \%$ \\
\hline 2015 & 74.492 & 167.133 & $44,57 \%$ \\
\hline 2016 & 80.511 & 86.000 & $93,61 \%$ \\
\hline 2017 & 26.115 & 43.491 & $60,04 \%$ \\
\hline
\end{tabular}

Sumber: Laporan Keuangan Bank Muamalat Indonesia (diolah)

Hasil analisis Net Profit Margin (NPM) Bank Muamalat Indonesia selama 5 (lima) tahun terakhir yang telah dihitung menunjukkan nilai yang berfluktuatif setiap tahunnya. Pada tahun 2013 nilai NPM adalah $67,14 \%$. Hal ini menunjukkan bahwa dari setiap transaksi 1 (satu) juta rupiah, Bank Muamalat Indonesia mampu menghasilkan keuntungan bersih sebesar Rp. 671.400, -. Kemudian pada tahun 2014 nilai NPM Bank Muamalat Indonesia. mengalami penurunan sebesar 28,48\% sehingga menjadi 38,66\%.

Pada tahun 2015 dan 2016 nilai NPM Bank Muamalat Indonesia kembali mengalami peningkatan yaitu $44,57 \%$ pada tahun 2015 , dan $93,61 \%$ pada tahun 2016 . Terjadinya peningkatan pada 2 (dua) tahun berturut-turut ini dikarenakan adanya peningkatan laba bersih dari tahun 2015 sampai dengan 2016. Tahun 2017 nilai NPM mengalami penurunan sebesar 33,57\% dibanding tahun sebelumnya, yaitu menjadi $60,04 \%$. 
Berdasarkan standar yang ditetapkan yaitu semakin tinggi Net Profit Margin (NPM), semakin baik operasi suatu bank. Nilai Net Profit Margin (NPM) tertinggi berada pada tahun 2016. Artinya pada tahun tersebut operasi Bank Muamalat Indonesia berada dalam kategori baik. Sedangkan nilai Net Profit Margin (NPM) terendah berada pada tahun 2014.

\section{Rasio Profitabilitas berdasarkan Return on Asset (ROA)}

Dengan Rumus berikut $R O A=\frac{\text { Laba Bersih }}{\text { Total Aktiva }} \times 100 \%$ Return on Asset (ROA) dapat dihitung sebagai berikut:

Tabel 4.2 Return on Asset (ROA) Bank Muamalat Indonesia

\begin{tabular}{|c|c|c|c|}
\hline Tahun & $\begin{array}{c}\text { Laba Bersih } \\
\text { (dalam jutaan } \\
\text { rupiah) }\end{array}$ & $\begin{array}{c}\text { Total Aktiva } \\
\text { (dalam jutaan } \\
\text { rupiah) }\end{array}$ & Return on Asset (ROA) \\
\hline 2013 & 475.847 & 54.694 .020 & $0,87 \%$ \\
\hline 2014 & 57.173 & 62.413 .310 & $0,09 \%$ \\
\hline 2015 & 74.492 & 57.172 .587 & $0,13 \%$ \\
\hline 2016 & 80.511 & 55.786 .397 & $0,14 \%$ \\
\hline 2017 & 26.115 & 61.696 .919 & $0,04 \%$ \\
\hline
\end{tabular}

Sumber: Laporan Keuangan Bank Muamalat Indonesia (diolah)

Hasil analisis Return on Assets (ROA) Selama 5 (lima) tahun terakhir terhitung mulai dari tahun 2013-2017, Bank Muamalat Indonesia memiliki nilai ROA yang cenderung menurun. Penurunan laba operasional terjadi karena adanya kenaikan beberapa pendapatan namun disertai dengan kenaikan bebanbeban non operasional dan beban operasional bank yang lebih besar seperti beban penghapusan aktiva, beban kerugian komitmen dan kontijensi, beban operasional lainnya yang didominasi oleh biaya personalia, serta beban administrasi dan umum. Selain itu juga, besarnya akumulasi penyusutan beberapa aset tetap Bank Muamalat Indonesia mengakibatkan aset tersebut menjadi kurang produktif.

Berdasarkan standar nilai ROA yang ditetapkan oleh Bank Indonesia (BI) yaitu jika nilai ROA berada diantara $0,5 \%$ - 1,25\% maka dapat dikategorikan cukup baik. Dari standar tersebut hanya pada tahun 2013, 2015, dan 2016 ROA Bank Muamalat Indonesia berada pada kategori baik dengan nilai masing-masing yaitu $0,87 \%, 0,13 \%$, dan $0,14 \%$.

\section{Rasio Profitabilitas berdasarkan Return on Equity (ROE)}

Dengan rumus berikut: $R O E=\frac{\text { Laba Bersih }}{\text { Ekuitas }} \times 100 \%$

Dapat dihitung nilai Return on Equity (ROE) adalah sebagai berikut:

Tabel 4.3 Return on Equity (ROE) Bank Muamalat Indonesia

\begin{tabular}{|c|c|c|c|}
\hline Tahun & $\begin{array}{c}\text { Laba Bersih } \\
\text { (dalam jutaan } \\
\text { rupiah) }\end{array}$ & $\begin{array}{c}\text { Ekuitas } \\
\text { (dalam jutaan } \\
\text { rupiah) }\end{array}$ & Return on Equity (ROE) \\
\hline 2013 & 475.847 & 4.291 .093 & $11,08 \%$ \\
\hline 2014 & 57.173 & 4.023 .951 & $1,42 \%$ \\
\hline 2015 & 74.492 & 3.550 .563 & $2,09 \%$ \\
\hline 2016 & 80.511 & 3.618 .746 & $2,22 \%$ \\
\hline 2017 & 26.115 & 5.545 .919 & $0,47 \%$ \\
\hline
\end{tabular}

Sumber: Laporan Keuangan Bank Muamalat Indonesia (diolah)

Hasil analisis Return on Equity (ROE) pada Bank Muamalat Indonesia selama 5 (lima) tahun terakhir mengalami fluktuasi. Nilai ROE tahun 2013 sebesar 11,08\%. Dan mengalami penurunan drastis sebesar 9,66\% pada tahun 2014 menjadi 1,42\%. Pada tahun berikutnya yaitu tahun 2015 dan 2016 nilai ROE kembali naik menjadi 2,09\% dan 2,22\%. Ditahun 2017 nilai ROE kembali mengalami penurunan menjadi $0,47 \%$.

Menurunnya nilai ROE Bank Muamalat Indonesia ini disebabkan oleh faktor risiko operasional. Risiko operasional terjadi dikarenakan sistem operasional dan prosedur maupun pengawasan yang tidak memenuhi kebutuhan perkembangan perbankan. Lemahnya sistem operasional akan berdampak pada meningkatnya biaya operasional dan pada akhirnya akan mengurangi laba usaha. 
Penurunan nilai ROE yang tajam terjadi pada tahun 2017. Penurunan tersebut di sebabkan karena menurunnya laba bersih Bank Muamalat Indonesia yang semula Rp.80.511.090.- (dalam jutaan) pada tahun 2016 menjadi Rp.26.115.563, - (dalam jutaan) pada tahun 2017. Selain karena turunnya laba bersih, faktor lain yang menyebabkan turunya nilai ROE disebabkan karena tingginya beban bagi hasil kepada nasabah sepanjang tahun 2017.

Sesuai dengan standar pengukuran tingkat ROE menurut Bank Indonesia (BI) yaitu 17,5\%. Jika dilihat dari tabel 4.3 nilai ROE selama 5 (lima) tahun terakhir berada dibawah standar yang ditetapkan, artinya ROE Bank Muamalat Indonesia periode 2013-2017 berada pada kategori tidak baik karena berada dibawah standar.

\section{Rasio Solvabilitas berdasarkan Capital Adequacy Ratio (CAR)}

Dengan rumus berikut: $C A R=\frac{\text { Modal Bank }}{\text { Aktiva Tertimbang Menurut Risiko (ATMR) }} \times 100 \%$

Nilai CAR dapat dihitung sebagai berikut:

Table 4.4 Capital Adequacy Ratio (CAR) Bank Muamalat Indonesia

\begin{tabular}{|c|c|c|c|}
\hline Tahun & $\begin{array}{c}\text { Modal Bank } \\
\text { (dalam jutaan } \\
\text { rupiah) }\end{array}$ & $\begin{array}{c}\text { ATMR } \\
\text { (dalam jutaan } \\
\text { rupiah) }\end{array}$ & $\begin{array}{c}\text { Capital Adequacy } \\
\text { Ratio (CAR) }\end{array}$ \\
\hline 2013 & 5.943 .244 & 34.414 .939 & $17,26 \%$ \\
\hline 2014 & 5.839 .159 & 41.334 .187 & $14,12 \%$ \\
\hline 2015 & 5.143 .373 & 37.713 .341 & $13,63 \%$ \\
\hline 2016 & 5.220 .000 & 40.978 .000 & $12,73 \%$ \\
\hline 2017 & 6.127 .413 & 44.984 .813 & $13,62 \%$ \\
\hline
\end{tabular}

Sumber: Laporan Tahunan Bank Muamalat Indonesia (diolah)

Pada tahun 2013 nilai CAR Bank Muamalat Indonesia yaitu 17,26\%. Kemudian pada tahun 2014 sampai 2015 nilai CAR mengalami penurunan menjadi 14,12\% pada tahun 2014, dan 13,63\% pada tahun 2015. Nilai CAR yang mengalami penurunan ini dikarenakan menurunnya modal inti yang disebabkan oleh rugi berjalan setelah pajak yang sebelumnya hanya sebesar Rp.860,17 miliar ditahun 2014 menjadi sebesar Rp.1,30 triliun ditahun 2015. Selama tahun 2015, Bank Muamalat Indonesia tidak melakukan corporate action dalam rangka penambahan modal. Pada tahun 2016 nilai CAR Bank Muamalat Indonesia mengalami kenaikan sebesar $0,37 \%$ dari tahun sebelumnya, sehingga menjadi $12,73 \%$. Pada tahun berikutnya nilai CAR juga mengalami kenaikan dari $12,73 \%$ menjadi $13,62 \%$. Peningkatan ini dikontribusi oleh komponen modal inti akibat proses penerbitan saham baru yang sedang berjalan dan beberapa calon investor potensial sudah menyiapkan dana. Atas setoran dana tersebut, Bank telah membukukannya sebagai tambahan setoran modal dalam tahun berjalan.

Berdasarkan standar Capital Adequacy Ratio (CAR) yang ditetapkan oleh Bank Indonesia (BI) yaitu sebesar $8 \%$ dapat dikatakan Bank tersebut berpredikat sehat. Karena nilai CAR Bank Muamalat Indonesia selama 5 (lima) tahun terakhir berada di atas 8\%, maka Bank Muamalat Indonesia dapat dikatakan berpredikat sehat.

\section{Rasio Solvabilitas berdasarkan Debt to Equity Ratio (DER)}

Rumus mencari DER adalah: DER $=\frac{\text { Total Hutang }}{\text { Total Ekuitas }} \times 100 \%$

Dengan rumus tersebut dapat diketahui nilai DER adalah sebagai berikut:

Tabel 4.5 Debt to Equity Ratio (DER) Bank Muamalat Indonesia

\begin{tabular}{|c|c|c|c|}
\hline Tahun & $\begin{array}{c}\text { Total Utang } \\
\text { (dalam jutaan } \\
\text { rupiah) }\end{array}$ & $\begin{array}{c}\text { Total Ekuitas } \\
\text { (dalam jutaan } \\
\text { rupiah) }\end{array}$ & Debt to Equity Ratio (DER) \\
\hline 2013 & 9.875 .163 & 4.291 .094 & $230,13 \%$ \\
\hline 2014 & 9.463 .143 & 4.023 .952 & $235,22 \%$ \\
\hline 2015 & 8.952 .097 & 3.550 .564 & $252,16 \%$ \\
\hline 2016 & 9.477 .756 & 3.619 .746 & $261,86 \%$ \\
\hline 2017 & 9.985 .546 & 5.545 .366 & $180,07 \%$ \\
\hline
\end{tabular}

Sumber: Laporan Keuangan Bank Muamalat Indonesia (diolah)

Ahmad Mukhlis, et.al. (Analisis Kinerja Keuangan Dengan Menggunakan Rasio-Rasio...) 
Hasil analisis Debt to Equity Ratio (DER) pada Bank Muamalat Indonesia periode 2013-2017 menunjukkan nilai yang cenderung naik. Walaupun nilai Debt to Equity Ratio (DER) Bank Muamalat Indonesia pada 5 (lima) tahun terakhir cenderung naik, tetapi tidak dapat dikategorikan baik karena melebihi standar yang ditetapkan yaitu semakin kecil nilai Debt to Equity Ratio (DER) maka semakin baik suatu bank dalam menutupi hutang-hutangnya, namun sebaliknya apabila semakin besar nilai Debt to Equity Ratio (DER) maka semakin tidak baik suatu bank dalam menutupi hutang-hutangnya.

Tingginya nilai Debt to Equity Ratio (DER) ini menandakan bahwa kemampuan bank untuk menutupi seluruh hutang-hutangnya dengan mengandalkan ekuitas yang dimiliki sangatlah kecil. Sehingga bank harus berusaha untuk memperbesar cadangan ekuitasnya secara bijak yaitu dengan melakukan manajemen permodalan secara cermat.

Standar pengukuran untuk Debt to Equity Ratio (DER) ini yaitu jika suatu bank memiliki nilai Debt to Equity Ratio (DER) tinggi, maka dapat dikatakan bank tersebut tidak memiliki kemampuan untuk membayar kewajiban jangka panjangnya. Begitu sebaliknya, jika nilai Debt to Equity Ratio (DER) lebih rendah, maka bank tersebut memiliki kemampuan untuk membayar kewajiban jangka panjang. Berdasarkan standar tersebut, nilai Debt to Equity Ratio (DER) Bank Muamalat Indonesia terendah berada pada tahun 2017, itu berarti pada tahun tersebut Bank Muamalat Indonesia mampu membayar kewajiban jangka panjangnya.

\section{Rasio Solvabilitas Berdasarkan Debt to Asset Ratio (DAR)}

Rumus DAR yaitu: DAR $=\frac{\text { Total Hutang }}{\text { Total Aktiva }} \times 100 \%$

Dengan rumus tersebut nilai DAR dapat dihitung sebagai berikut:

Tabel 4.6 Debt to Asset Ratio (DAR) Bank Muamalat Indonesia

\begin{tabular}{|c|c|c|c|}
\hline Tahun & $\begin{array}{c}\text { Total Utang } \\
\text { (dalam jutaan } \\
\text { rupiah) }\end{array}$ & $\begin{array}{c}\text { Total Aktiva } \\
\text { (dalam jutaan } \\
\text { rupiah) }\end{array}$ & Debt to Asset Ratio (DAR) \\
\hline 2013 & 9.875 .163 & 54.694 .020 & $18,05 \%$ \\
\hline 2014 & 9.463 .143 & 62.413 .310 & $15,16 \%$ \\
\hline 2015 & 8.952 .097 & 57.172 .587 & $15,65 \%$ \\
\hline 2016 & 9.477 .756 & 55.786 .397 & $16,98 \%$ \\
\hline 2017 & 9.985 .546 & 61.696 .919 & $16,18 \%$ \\
\hline
\end{tabular}

Sumber: Laporan Keuangan Bank Muamalat Indonesia (diolah)

Dapat dilihat bahwa pada tahun 2013 nilai DAR Bank Muamalat Indonesia yaitu 18,05\%. Pada tahun berikutnya nilai DAR mengalami penurunan sebesar 2,89\%, sehingga nilai DAR pada tahun 2014 menjadi 15,16\%. Pada tahun 2015 nilai DAR Bank Muamalat Indonesia mengalami peningkatan dari tahun sebelumnya, sehingga menjadi $15,65 \%$. Pada tahun berikutnya nilai DAR Bank Muamalat Indonesia kembali meningkat sebesar 1,33\%, sehingga menjadi $16,98 \%$ pada tahun 2016. Nilai DAR yang terus meningkat pada tahun 2015 dan tahun 2016 ini menunjukkan bahwa Bank Muamalat Indonesia dalam keadaan insolven dan lebih berisiko. Pada tahun 2017 nilai DAR mengalami penurunan sebesar $0,8 \%$, sehingga nilai DAR Bank Muamalat Indonesia menjadi $16,18 \%$.

Berdasarkan standar yang ditetapkan yaitu semakin besar nilai Debt to Assets Ratio (DAR) maka semakin tidak baik, begitu pula sebaliknya. Sesuai dengan standar tersebut nilai Debt to Assets Ratio (DAR) Bank Muamalat Indonesia tertinggi berada pada tahun 2013. Artinya, pada tahun 2013 bank dalam keadaan tidak memiliki cukup dana untuk melunasi utang (insolven) dan tidak mampu menutupi utangutangnya dengan aktiva yang dimiliki karena total utang yang lebih besar daripada total aktivanya. Hal itu dikhawatirkan semakin membuat bank lebih berisiko dan akan sulit dalam memperoleh pinjaman.

\section{Pengukuran Kinerja dengan Economic Value Added (EVA)}

Rumus Economic Value Added (EVA): EVA = NOPAT-Capital Charges

Berikut ini perhitungan Economic Value Added (EVA) Bank Muamalat Indonesia Periode 20132017: 
Tabel 4.7 Economic Value Added (EVA) Bank Muamalat Indonesia

\begin{tabular}{|c|c|c|c|}
\hline Tahun & $\begin{array}{c}\text { NOPAT } \\
\text { (dalam jutaan } \\
\text { rupiah) }\end{array}$ & $\begin{array}{c}\text { Capital Charges } \\
\text { (dalam jutaan } \\
\text { rupiah) }\end{array}$ & $\begin{array}{c}\text { Economic Value } \\
\text { Added (EVA) }\end{array}$ \\
\hline 2013 & 2.429 .961 & 2.989 .080 & -559.119 \\
\hline 2014 & 2.446 .490 & 3.398 .747 & -952.257 \\
\hline 2015 & 2.415 .190 & 1.650 .351 & 764.839 \\
\hline 2016 & 1.814 .788 & 2.265 .522 & -450.734 \\
\hline 2017 & 1.810 .036 & 15.530 .912 & -13.720 .876 \\
\hline
\end{tabular}

Sumber: Laporan Keuangan Bank Muamalat Indonesia (diolah)

Hasil penelitian Economic Value Added (EVA) pada Bank Muamalat Indonesia periode 2013-2017 menunjukkan nilai yang cenderung negatif setiap tahunnya, terkecuali pada tahun 2015 nilai Economic Value Added (EVA) bernilai positif.

Berdasarkan konsep Economic Value Added (EVA) apabila bernilai negatif (EVA<0) artinya bank tidak mampu memberikan nilai tambah bagi para pemegang saham. Apabila bernilai positif (EVA>0) artinya bank mampu memberikan nilai tambah bagi para pemegang saham.

Nilai Economic Value Added (EVA) yang negatif pada tahun 2013, 2014, 2016, dan 2017 yang diperoleh Bank Muamalat Indonesia secara umum terjadi karena biaya ekuitas (capital charge) lebih besar daripada laba bersih yang dihasilkan. Hal ini dikarenakan tingginya persentase biaya ekuitas (saham) yang dapat disebabkan oleh beberapa hal, diantaranya earning per share (EPS), harga saham saat ini, dan jumlah ekuitas. Apabila dilihat dari ikhtisar saham pada laporan keuangan tahunan, Bank Muamalat Indonesia selama ini belum pernah melakukan penjualan saham. Hal ini menyebabkan tingginya biaya ekuitas bank.

Tahun 2015, Economic Value Added (EVA) Bank Muamalat Indonesia bernilai positif (EVA> 0). Nilai yang positif ini disebabkan karena laba bersih yang berhasil didapatkan perusahaan mampu untuk menutupi seluruh modal perusahaan yang minus selama satu tahun. Sehingga, dengan nilai EVA yang positif pada tahun 2015 ini Bank Muamalat Indonesia menunjukkan bahwa manajemen berhasil dalam menciptakan nilai tambah bagi perusahaan dan para pemegang saham.

\section{SIMPULAN DAN REKOMENDASI}

\section{Simpulan}

1. Dari hasil pengukuran Rasio Profitabilitas berdasarkan nilai NPM, ROA, dan ROE, kinerja keuangan terbaik dicapai pada tahun 2013 dan 2016. Penurunan drastis terjadi pada nilai ROE tahun 2017 dengan nilai $0,47 \%$, hal itu disebabkan oleh menurunnya laba bersih dan tingginya beban bagi hasil kepada nasabah sepanjang tahun 2017.

2. Adapun nilai CAR Bank Muamalat Indonesia selama periode tersebut, semuanya diatas $8 \%$. Hal itu menunjukkan bahwa Bank Muamalat Indonesia tergolong sehat. Namun nilai DER dan DAR yang cenderung naik mengindikasikan bahwa Bank Muamalat Indonesia memiliki risiko utang yang cukup tinggi.

3. Nilai EVA yang diperoleh tahun 2015 adalah lebih besar dari nol yaitu Rp.764.839,- (dalam jutaan rupiah) artinya pada tahun 2015 Bank Muamalat Indonesia mampu meningkatkan nilai perusahaan. Sedangkan pada tahun 2013, 2014, 2016, dan 2017 nilai EVA kurang dari nol artinya Bank Muamalat Indonesia tidak mampu menghasilkan nilai tambah ekonomi bagi perusahaannya. Dengan demikian kinerja terbaik Bank Muamalat Indonesia dicapai pada tahun 2015.

\section{Rekomendasi}

Bank Muamalat Indonesia hendaknya mengoptimalkan nilai Economic Value Added (EVA). Untuk mengoptimalkan nilai Economic Value Added (EVA) Bank Muamalat Indonesia dapat dilakukan dengan memilih investasi yang memaksimumkan tingkat pengembalian dan meminimumkan tingkat biaya modal, sehingga nilai tambah ekonomis menjadi optimal. Selain melakukan investasi, Bank Muamalat Indonesia dinilai perlu melakukan penjualan saham, mengingat selama ini Bank Muamalat Indonesia belum pernah melakukan penjualan saham. Selain dapat mengoptimalkan nilai tambah ekonomis bagi 
perusahaan, hal-hal tersebut juga dapat meningkatkan nilai Return on Asset (ROA), Return on Equity (ROE), dan Net Profit Margin (NPM) bank untuk menutupi kerugian-kerugian yang nantinya dapat terjadi, serta dapat menurunkan nilai Debt to Equity Ratio (DER) dan Debt to Asset Ratio (DAR) sehingga resiko utang bank dapat diminimalisir. Selain itu, nilai Capital Adequacy Ratio (CAR) yang sudah sangat baik tersebut bisa dipertahankan dimasa yang akan datang, sehingga kinerja Bank Muamalat Indonesia dapat dinilai baik dan bisa menarik minat para investor untuk menanamkan modal di Bank Muamalat Indonesia.

\section{DAFTAR PUSTAKA}

Sumber Buku:

Fahmi, Irham. 2014. Analisis Kinerja Keuangan. Bandung: Alfabeta.

Jumingan. 2014. Analisis Laporan Keuangan. Jakarta: PT. Bumi Aksara.

Kasmir. 2016. Pengantar Manajemen Keuangan. Jakarta: Prenadamedia Group.

Rudianto. 2013. Akuntansi Manajemen: Informasi Untuk Pengambilan Keputusan Strategis, Jakarta: Erlangga.

Sumber Internet:

www.bankmuamalat.co.id 